Journal of Healthcare Technology and Medicine Vol. 3 No. 1 April 2017

Universitas Ubudiyah Indonesia

e-ISSN : 2615-109X

\title{
HUBUNGAN POLA MAKAN DAN AKTIVITAS FISIK DENGAN STATUS GIZI PADA REMAJA DI SMA NEGERI 2 SIGLI KABUPATEN PIDIE
}

The Relationship Of Eating Patterns And Physical Activities With Nutritional

Status In Adolescents In

Sma Negeri 2 Sigli Pidie District

Ismiati $^{1}$, Darma suri ${ }^{2}$

${ }^{1,2}$ Fakultas Ilmu Kesehatan, Universitas Ubudiyah Indonesia, Banda Aceh

Email: ismiati@uui.ac.id

\begin{abstract}
ABSTRAK
Gizi merupakan masalah ekologi yang merupakan hasil akhir dari interaksi multi faktor. Berdasarkan estimasi WHO, saat ini, 1,6 miliar orang dewasa di seluruh dunia mengalami berat badan berlebih (overweight), dan sekurang-kurangnya 400 juta diantaranya mengalami obesitas. Prevalensi gizi remaja umur 16-18 tahun berdasarkan indeks massa tubuh (IMT) menurut provinsi tahun 2010 adalah sangat kurus 1,6\%, kurus 7,1\%, normal 89,7\% dan gemuk $1,4 \%$. Tujuan penelitian untuk mengetahuai hubungan pola makan dan aktivitas fisik dengan status gizi pada remaja.Penelitian ini bersifat analitik dengan desain crossectional. Populasi dalam penelitian ini remaja kelas XI di SMA Negeri 2 Sigli Kabupaten Pidie tediri dari 7 lokal berjumlah 234 orang. Teknik pengambilan sampel secara stratified random sampling berjumlah 70 responden. Penelitian ini telah dilaksanakan di SMA Negeri 2 Sigli Kabupaten Pidie pada tanggal 20-22 Mei 2017. Pengumpulan data dilakukan dengan menyebarkan kuesioner dan antropometry. Analisa data dilakukan dengan menggunakan program komputer.Hasil penelitian didapatkan bahwa ada hubungan antara pola makan dengan status gizi remaja di SMA Negeri 2 Sigli Kabupaten Pidie dengan $\mathrm{P}$ value $0,000(<\alpha 0,05)$, ada hubungan antara aktivitas fisik dengan status gizi remaja di SMA Negeri 2 Sigli Kabupaten Pidie dengan P value 0,000 $(<\alpha$ 0,05). Dari data di atas dapat disimpulkan bahwa status gizi normal banyak dijumpai pada responden dengan pola makan baik dan aktivitas fisik yang teratur. Bagi remaja diharapkan agar dapat menerapkan pola makan yang sehat dan melakukan aktivitas fisik yang teratur untuk menjaga keseimbangan gizi dan mengurangi dampak gizi kurang dan lebih.
\end{abstract}

\section{Kata Kunci : Pola Makan, Aktivitas Fisik, Status Gizi Remaja}

\begin{abstract}
Nutrition is an ecological problem that is the end result of multi-factor interactions. Based on WHO estimates, currently, 1.6 billion adults around the world are overweight, and at least 400 million are obese. The nutritional prevalence of adolescents aged 16-18 years based on body mass index (BMI) by province in 2010 was very thin 1.6\%, thin $7.1 \%$, normal $89.7 \%$ and fat 1.4\%. The purpose of this study was to determine the relationship of eating patterns and physical activity with nutritional status in adolescents. This research is analytic with cross-sectional design. The population in this study was class XI teenagers in SMA Negeri 2 Sigli, Pidie Regency consisting of 7 local people totaling 234 people. Stratified random sampling technique was 70 respondents. This research was conducted at SMA Negeri 2 Sigli, Pidie Regency on May 20-22, 2017. Data collection was carried out by distributing questionnaires and anthropometry. Data analysis was performed using a computer program. The results showed that there was a
\end{abstract}


Journal of Healthcare Technology and Medicine Vol. 3 No. 1 April 2017

Universitas Ubudiyah Indonesia

e-ISSN : 2615-109X

relationship between eating patterns with adolescent nutritional status in SMA Negeri 2 Sigli, Pidie District with a P value of 0,000 $(<\alpha$ 0.05), there was a relationship between physical activity and nutritional status of adolescents in SMA Negeri 2 Sigli, Pidie Regency with a $P$ value of $0,000(<\alpha$ 0.05). From the above data it can be concluded that the normal nutritional status is often found in respondents with good eating patterns and regular physical activity. Adolescents are expected to be able to adopt healthy eating patterns and carry out regular physical activities to maintain nutritional balance and reduce the impact of under-nutrition.

Keywords: Diet, Physical Activity, Adolescent Nutrition Status

\section{PENDAHULUAN}

Konsumsi gizi makanan pada seseorang dapat menentukan tercapainya tingkat kesehatan, atau sering disebut status gizi. Apabila konsumsi gizi makanan pada seseorang tidak seimbang dengan kebutuhan tubuh maka akan terjadi kesalahan akibat gizi (malnutrition). Malnutrition ini mencakup kelebihan nutrisi/gizi disebut gizi lebih (overnutrition), dan kekurangan gizi atau gizi kurang (undernutrition) (Notoadmodjo, 2007).

World Health Organisation (WHO) menjelaskan bahwa remaja adalah suatu masa ketika individu berkembang dari saat pertama kali menunjukkan tanda-tanda seksual sekundernya sampai saat mencapai kematangan seksual. Individu yang mengalami perkembangan psikologis dan pola identifikasi dari kanak-kanak menjadi dewasa. Terjadi peralihan dan ketergantungan sosial- ekonomi yang penuh kepada keadaan relatif lebih mandiri (Sarwono, 2008).

Studi pendahuluan yang penulis lakukan di SMA Negeri 2 Sigli Kabupaten Pidie didapatkan data bahwa jumlah siswa adalah 667 orang terdiri dari 228 orang kelas X, 234 orang kelas XI dan 205 orang kelas XII. Dari 5 orang siswa yang diwawancarai didapatkan informasi bahwa 3 orang $(60 \%)$ diantaranya kurang melakukan aktivitas olahraga karena lelah pulang sekolah, 2 orang (40\%) kebiasaan mengkonsumsi cemilan seperti coklat dan es cream, makanan siap saji, berangkat ke sekolah menggunakan mobil atau sepeda motor. Selain itu dari 3 orang siswa yang gemuk diwawancarai didapatkan informasi bahwa makan teratur 3 kali sehari dan jarang melakukan olahraga sedangkan 3 orang dengan postur tubuh yang kurus memiliki kebiasaan konsumsi makanan pokok dengan teratur ditambah dengan kebiasaan makanan cemilan tanpa disertai olahraga yang teratur. Fenomena tersebut perlu dikaji lebih dalam untuk dilakukan suatu penelitian guna mengetahui hubungan pola makan dan aktivitas fisik dengan status gizi. 
Journal of Healthcare Technology and Medicine Vol. 3 No. 1 April 2017

Universitas Ubudiyah Indonesia

e-ISSN : 2615-109X

\section{METODE PENELITIAN}

Penelitian ini adalah bersifat analitik dengan pendekatan cross sectional study untuk mengetahui hubungan pola makan dan aktivitas fisik dengan status gizi pada remaja di SMA Negeri 2 Sigli Kabupaten Pidie. Sampel pada penelitian ini adalah remaja kelas XI di SMA Negeri 2 Sigli Kabupaten Pidie berjumlah 70 responden. Teknik pengambilan sampel dalam penelitian ini dilakukan secara stratified random sampling yaitu, suatu cara pengambilan sampel yang digunakan bila anggota populasinya tidak homogen yang terdiri atas kelompok yang homogeny atau berstrata secara proporsional (Hidayat, A, 2007). Untuk mengukur hubungan antar variabel akan dilakukan dengan menggunakan program komputer yaitu menggunakan Statistik Product Service Solution (SPSS) versi 18,0. Hubungan antar variabel dilihat dengan menggunakan uji continuity correction. Penilaian dilakukan sebagai berikut :

1) Jika $p$ value $\leq 0,05$ maka dapat disimpulkan bahwa Ho ditolak dan Ha diterima.

2) Jika p value > 0,05 maka disimpulkan Ho diterima dan Ha ditolak.

\section{HASIL DAN PEMBAHASAN}

\section{a. Hubungan Pola Makan dengan Status Gizi}

Hasil pengolahan data bivariat dengan menggunakan program komputer didapatkan $\mathrm{p}$ value 0,000 . Hubungan pola makan dengan status gizi dapat dilihat pada tabel berikut :

\section{Tabel 1}

Hubungan Pola Makan dengan Status Gizi Remaja di SMA Negeri 2 Sigli Kabupaten Pidie

\begin{tabular}{|c|c|c|c|c|c|c|c|c|c|c|}
\hline \multirow{3}{*}{$\begin{array}{l}\mathbf{N} \\
\mathbf{0}\end{array}$} & \multirow{3}{*}{$\begin{array}{c}\text { Pola } \\
\text { Makan }\end{array}$} & \multicolumn{6}{|c|}{ Status Gizi } & \multirow{3}{*}{ Total } & \multirow{3}{*}{$\begin{array}{c}\text { Nila } \\
\alpha\end{array}$} & \multirow{2}{*}{$\begin{array}{c}P \text { - } \\
\text { value }\end{array}$} \\
\hline & & \multicolumn{2}{|c|}{ Kurus } & \multicolumn{2}{|c|}{ Normal } & \multicolumn{2}{|c|}{ Gemuk } & & & \\
\hline & & $\mathbf{F}$ & $\%$ & $\mathbf{F}$ & $\%$ & $\mathbf{F}$ & $\%$ & & & \\
\hline 1 & Baik & 11 & 26,8 & 27 & 65,9 & 3 & 7,3 & 41 & & \\
\hline 2 & Kurang & 3 & 10,3 & 10 & 34,5 & 16 & 55,2 & 29 & & \\
\hline \multicolumn{2}{|c|}{ Total } & 14 & 20,0 & 37 & 52,9 & 19 & 27,1 & 70 & 0,05 & 0,000 \\
\hline
\end{tabular}

Berdasarkan tabel 1 di atas dapat dilihat bahwa dari 41 responden dengan pola makan baik terdapat status gizi normal sebanyak 27 responden (65,9\%). Sedangkan dari 29 responden dengan pola makan kurang baik terdapat status gizi dalam normal sebanyak 10 responden (34,5\%). Berdasarkan perhitungan uji Pearson Chi Square, diperoleh nilai p = 
Journal of Healthcare Technology and Medicine Vol. 3 No. 1 April 2017

Universitas Ubudiyah Indonesia

e-ISSN : 2615-109X

0,000 . Nilai tersebut lebih kecil dari $\alpha=0,05$, dengan demikian ada hubungan antara pola makan dengan status gizi atau Hipotesa alternatif (Ha) diterima.

\section{b. Hubungan Aktivitas Fisik dengan Status Gizi}

Hasil pengolahan data bivariat dengan menggunakan program komputer didapatkan $\mathrm{p}$ value 0,000 . Hubungan aktivitas fisik dengan status gizi dapat dilihat pada tabel berikut :

\section{Tabel 2}

Hubungan Aktivitas Fisik dengan Status Gizi Remaja di SMA Negeri 2 Sigli Kabupaten Pidie

\begin{tabular}{|c|c|c|c|c|c|c|c|c|c|c|}
\hline \multirow{3}{*}{$\begin{array}{l}\mathbf{N} \\
\mathbf{0}\end{array}$} & \multirow{3}{*}{$\begin{array}{c}\text { Aktivitas } \\
\text { Fisik } \\
\end{array}$} & \multirow{2}{*}{\multicolumn{4}{|c|}{$\frac{\text { Status Giz }}{\text { Normal }}$}} & \multirow{2}{*}{\multicolumn{2}{|c|}{ Gemuk }} & \multirow{3}{*}{ Total } & \multirow{2}{*}{$\begin{array}{c}\text { Nila } \\
\alpha\end{array}$} & \multirow{2}{*}{$\begin{array}{c}P \text { - } \\
\text { value }\end{array}$} \\
\hline & & & & & & & & & & \\
\hline & & $\mathbf{F}$ & $\%$ & $\mathbf{F}$ & $\%$ & $\mathbf{F}$ & $\%$ & & & \\
\hline 1 & Teratur & 5 & 13,5 & 31 & 83,8 & 1 & 2,7 & 37 & & \\
\hline 2 & $\begin{array}{l}\text { Tidak } \\
\text { Teratur }\end{array}$ & 9 & 27,3 & 6 & 18,2 & 18 & 54,5 & 33 & & \\
\hline & & 14 & 20,0 & 37 & 52,9 & 19 & 27,1 & 70 & & \\
\hline
\end{tabular}

Berdasarkan tabel 2 dapat dilihat bahwa dari 37 responden dengan aktivitas fisik teratur terdapat status gizi normal sebanyak 31 responden (83,8\%). Sedangkan dari 33 responden dengan aktivitas fisik tidak teratur terdapat status gizi dalam normal sebanyak 6 responden $(18,2 \%)$. Berdasarkan perhitungan uji Pearson Chi Square, diperoleh nilai $\mathrm{p}=$ 0,000 . Nilai tersebut lebih kecil dari $\alpha=0,05$, dengan demikian ada hubungan antara aktivitas fisik dengan status gizi atau Hipotesa alternatif (Ha) diterima.

Berdasarkan analisa data di atas menunjukkan bahwa dari 41 responden dengan pola makan baik terdapat status gizi normal sebanyak 27 responden $(65,9 \%)$. Sedangkan dari 29 responden dengan pola makan kurang baik terdapat status gizi dalam normal sebanyak 10 responden (34,5\%). Berdasarkan perhitungan uji continuity Correction, diperoleh nilai $\mathrm{p}=0,000$. Nilai tersebut lebih kecil dari $\alpha=0,05$, dengan demikian ada hubungan antara pola makan dengan status gizi.

Hasil penelitian di atas menunjukkan bahwa status gizi normal lebih banyak dijumpai pada responden dengan pola makan yang baik. Sedangkan responden dengan pola makan yang kurang baik cenderung tidak mengalami kegemukan. Hal ini bisa disebabkan karena 
Journal of Healthcare Technology and Medicine Vol. 3 No. 1 April 2017

Universitas Ubudiyah Indonesia

e-ISSN : 2615-109X

pada responden dengan pola makan yang baik dapat memilih makanan yang tidak seimbang dan makan yang teratur.

Gizi seimbang adalah susunan menu sehari-hari yang mengandung zat gizi dalam jenis dan jumlah yang sesuai dengan kebutuhan tubuh, dengan memperhatikan prinsip keanekaragaman atau variasi makanan, aktivitas fisik, hidup bersih, dan berat badan ideal. Gizi seimbang pun harus dibarengi aspek sehat, termasuk aspek kebersihan (makanan, peralatan makan, cuci tangan dst) dan aspek keamanan, agar tidak kehilangan sebagian maknanya (Sari, 2011).

Hasil penelitian ini sejalan dengan penelitian yang dilakukan oleh Santy (2006) tentang "Faktor-faktor yang berhubungan dengan Indeks Massa Tubuh (IMT) remaja putri di Kota Bukittinggi Tahun 2006". Hasil penelitian menunjukkan rata-rata IMT rematri adalah $20,69 \mathrm{~kg} / \mathrm{m} 2+2,63$. Proporsi siswi yang mempunyai IMT $<18,5 \mathrm{~kg} / \mathrm{m} 2$ sebesar $19,9 \%$ dengan penyebaran 14,1\% kekurangan gizi tingkat ringan dan 5,8\% kekurangan gizi tingkat berat. Rata-rata asupan energi adalah 1694 kalori. Rata-rata kontribusi protein terhadap total energi sebesar $11,8 \%$, lemak 26,7\% dan karbohidrat 58,7\%. Rata-rata asupan energi dibandingkan AKG adalah total energi 77\%, protein 93,6\%, lemak 65,3\% dan karbohidrat $84,7 \%$. Hasil analisis bivariat menunjukkan ada hubungan bermakna antara total energi, kebiasaan makan dan citra tubuh dengan IMT remaja.

Berdasarkan uraian di atas peneliti dapat berasumsi bahwa pola makan yang baik dan sehat dapat menjaga status gizi dan menghindari risiko obesitas dengan mengurangi konsumsi makanan yang mengandung lemak yang tinggi, mengandung minyak,margarin, sumber protein hewani yang banyak mengandung kolesterol. Dengan mengatur pola makan yang baik dan gizi seimbang dapat memenuhi kebutuhan gizi pada remaja.

Berdasarkan analisa data dapat diketahui bahwa responden dengan aktivitas fisik yang teratur terdapat status gizi normal sebanyak 31 responden $(83,8 \%)$. Sedangkan dengan aktivitas fisik kurang tidak teratur terdapat status gizi dalam normal sebanyak 6 responden $(18,2 \%)$. Berdasarkan perhitungan uji continuity Correction, diperoleh nilai $\mathrm{p}=0,000$. Nilai tersebut lebih kecil dari $\alpha=0,05$, dengan demikian ada hubungan antara aktivitas fisik dengan status gizi atau Hipotesa alternatif (Ha) diterima.

Hasil penelitian di atas menunjukkan status gizi normal pada remaja lebih banyak terdapat pada responden dengan aktivitas fisik yang baik daripada responden dengan 
Journal of Healthcare Technology and Medicine Vol. 3 No. 1 April 2017

Universitas Ubudiyah Indonesia

e-ISSN : 2615-109X

aktivitas yang kurang. Hal ini disebabkan karena kurangnya aktivitas menyebabkan penumpukan lemak pada tubuh.

Menurut teori Potter dan Perry (2009), keuntungan pertama olahraga adalah mempertahankan dan meningkatkan kemampuan fungsional. Olahraga seperti berjalan akan membangun daya tahan tubuh, meningkatkan tonus otot, meningkatkan fleksibilitas sendi, memperkuat tulang, mengurangi stres, dan membantu menurunkan berat badan. Keuntungan lainnya adalah meningkatkan peningkatan fungsi kardiovaskuler, perbaikan profil lipoprotein plasma, peningkatan tingkat metabolik, peningkatan waktu pengosongan gastroinstentinal, penurunan risiko cedera akibat kecelakaan jatuh, pencegahan penyakit depresi, dan peningkatan kualitas.

Aktivitas fisik adalah gerakan yang dilakukan oleh otot tubuh dan sistem penunjangnya. Aktivitas fisik memerlukan energi di luar kebutuhan untuk metabolisme basal. Selama aktivitas fisik, otot membutuhkan energi di luar metabolisme untuk bergerak, sedangkan jantung dan paru-paru memerlukan tambahan energi untuk mengantarkan zat-zat gizi dan oksigen ke seluruh tubuh dan untuk mengeluarkan sisa-sisa dari tubuh. Banyaknya energi yang dikeluarkan tergantung pada berapa banyak otot yang bergerak, berapa lama dan berapa berat pekerjaan yang dilakukan. Seseorang yang gemuk menggunakan lebih banyak energi untuk melakukan suatu pekerjaan yang dilakukan daripada orang yang kurus (Almatsier, 2009).

Hasil penelitian ini sejalan dengan penelitian yang dilakukan oleh Nizar (2002) tentang "Faktor-Faktor yang Berhubungan dengan Status Gizi Remaja Putri pada Sekolah Menengah Umum Negeri (SMUN) dan Madrasah Aliyah Negeri (MAN) di Kota Padang Propinsi Sumatera Barat Tahun 2002". Hasil penelitian ini mendapatkan proporsi responden yang mempunyai status gizi kurang sebesar 30.7\% dengan penyebaran $23.9 \%$ dengan status kekurangan gizi tingkat ringan (IMT 17.0 -18.5) dan 6.8\% kekurangan gizi tingkat berat (IMT 17.0). Sebagian besar responden mempunyai tingkat konsumsi zat gizi kurang (74,7\% tingkat konsumsi energi kurang, 56,0\% tingkat konsumsi protein kurang, 68,6\% tingkat konsumsi lemak kurang dan 58,4\% tingkat konsumsi karbohidrat kurang), sebanyak 49,5\% responden mempunyai persepsi terhadap ukuran tubuh kurang, 51,2\% mempunyai aktivitas fisik tinggi, 47,1\% mempunyai kebiasan makan kurang, 41,3\% mempunyai pengetahuan 
Journal of Healthcare Technology and Medicine Vol. 3 No. 1 April 2017

Universitas Ubudiyah Indonesia

e-ISSN : 2615-109X

gizi kurang, 30,0\% mempunyai riwayat penyakit dan $66,3 \%$ mempunyai penghasilan tinggi.

Berdasarkan uraian di atas peneliti dapat berasumsi bahwa aktivitas fisik yang baik dengan olahraga dapat menurunkan risiko obesitas dan menstabilkan tekanan darah, meningkatkan kemampuan jantung sehingga dapat bekerja lebih maksimal. Seseorang sangat dianjurkan untuk melakukan olah raga sesuai dengan kapasitas masing-masing. Jenis olahraga yang dapat seperti jalan kaki cepat, earobik, berenang, jogging, dan bersepeda.

\section{KESIMPULAN}

Berdasarkan hasil penelitian peneliti dapat disimpulkan sebagai berikut:

1. Ada hubungan antara pola makan dengan status gizi remaja di SMA Negeri 2 Sigli Kabupaten Pidie dengan P value 0,000 $(<\alpha 0,05)$.

2. Ada hubungan antara aktivitas fisik dengan status gizi remaja di SMA Negeri 2 Sigli Kabupaten Pidie dengan P value 0,000 $(<\alpha 0,05)$.

\section{DAFTAR PUSTAKA}

Achadi, Endang, 2007, Gizi dan Kesehatan Masyarakat, Edisi Revisi Rajawali PerJakarta.

Almatsier, 2009, Prinsip Dasar Ilmu Gizi, Cetakan ke VII, Gramedia Pustaka Utama, Jakarta.

Hidayat, 2009, Metode Penelitian Kebidanan \& Teknik Analisis Data, Edisi kedua Salemba Medika, Jakarta.

Kartasapoetra dan Marsetyo, 2008, Ilmu Gizi : Korelasi Gizi Kesehatan dan Prodiktivitas Kerja, Rineka Cipta, Jakarta.

Potter dan Perry, 2009, Fundamental Of Nursing, Buku 1, Edisi 7, Salemba Medika, Jakarta.

Rikesdas, 2010, Laporan Nasional Riset Kesehatan Dasar Rikerdas, Badan Penelitian dan Pengembangan Departemen Kesehatan RI tahun 2010.

Santy, 2006, Faktor-faktor yang Berhubungan dengan Indeks Massa Tubuh IMT Remaja Putri di Kota $\quad$ Bukittinggi $\quad$ Tahun 2006,http://www.digilib.ui.ac.id/opac/themes/libri2/detail.jsp?id=106943 (Diakses 6 Januari 2012).

Santoso dan Rianti, 2004, Kesehatan dan Gizi, Rineka Cipta, Jakarta.

Sarwono Sarlito W, 2008, Psikologi Remaja, Raja Grafindo, Jakarta.

Supariasa, dkk, 2002, Penilaian Status Gizi, EGC, Jakarta.

Umar, 2005, Metodelogi Penelitian Untuk Skripsi dan Tesis Bisnis, Rajawali Pers, Jakarta. 